\title{
Energy Accounting of Irrigated Wheat Production to Post Production (Baking Bread) in Doroodzan, Fars Province, Iran
}

\author{
Seied Mohsen Taghay and Teodoro C. Mendoza \\ Crop Science Cluster, College of Agriculture, University of the Philippines Los Baños, \\ Laguna, Philippines
}

\begin{abstract}
The total energy input (TEI) of irrigated wheat in Fars province, Iran, was estimated at 901 liter diesel oil equivalent per hectare (LDOE ha ${ }^{-1}$ ) (423 LDOE or $4819 \mathrm{Mcal},(47 \%)$ and $478.14 \mathrm{LDOE}$ or $5454 \mathrm{Mcal},(53 \%)$ for wheat production and post production, respectively. The TEI for 1 ton wheat was estimated at $200 \mathrm{LDOE}$ and for 1 ton of bread at $181 \mathrm{LDOE}$ (wheat bread at $28 \%$ moisture). The direct use of fossil fuel oil in land preparation, planting, harvesting and transportation was estimated at $106 \mathrm{LDOE} \mathrm{ha}^{-1}$. The applications of fertilizer and pesticide contributed about $40 \%$ of the total energy bill in production while it was larger in baking the bread at $72.3 \mathrm{LDOE}$ ton $^{-1}$ or $75 \%$ of the energy costs of post production. At $4515 \mathrm{~kg} \mathrm{ha}^{-1}$ average yield of irrigated wheat in Fars province, Iran, the energy output was estimated at $15848 \mathrm{Mcal}$ for raw wheat, $13409.55 \mathrm{Mcal}$ for bread and $2895 \mathrm{Mcal}$ for straw. The energy balance for raw wheat production (field level) was estimated at 3.3. Post- production (baking bread) consumed a lot of energy. The estimated energy balance was 1.3. Measures on how to reduce the energy bill for wheat production and for post-production (baking bread) are discussed.
\end{abstract}

Keywords: energy balance, energy input, energy output, liter diesel oil equivalent (LDOE), national average yield, organic farming

Correspondence: TCMendoza Address: College of Agriculture, University of the Philippines Los Baños, Laguna, Philippines Email: ecofarm.mndz2011@gmail.com Tel/Fax: 0495362217 / 5362468

DOI: $10.32945 /$ atr3323.2011 
Wheat (Triticum aestivum L.) is among the oldest and most extensively grown of all crops (Hung et al., 2008). It is the main cereal cultivated throughout the world along with rice, barley, and maize. Wheat cultivar has been developed for different qualities in accordance with the development of genetic recombination (Hung et al., 2008). It is also grown under irrigated as well as rainfed conditions. Under rainfed condition, the wheat crop is exposed to mild and severe drought stress at any stages of crop development (Singh et al., 2005). In Iran, wheat is grown in both irrigated and rainfed conditions with a national production of 14.3 million tons in 2005 . At least $40 \%$ of Iran's wheat is rainfed with an average yield of only $0.8 \mathrm{t} \mathrm{ha}^{-1}$. However, even under the irrigated land, the average wheat yield in Iran rarely exceeds $3 \mathrm{tha}^{-1}$, which is slightly higher than the world average of $2.6 \mathrm{t} \mathrm{ha}^{-1}$ (http://www. fao.org/docrep/007/J5051e/j5051e07.htm). The average yield, however in Doroodzan dam, Fars province, Iran was at $4.5 \mathrm{t} \mathrm{ha}^{-1}$.

There is a close relationship between agriculture and energy. Agriculture is an energy user (oil for tillage, farm input applications, irrigation, etc.) and energy supplier in the form of biomass (Alam et al., 2005). Energy use in agriculture had increased due to increased energy inputs (fertilizer) to maximize yield and minimize labour intensive practices (mechanization) or both (Esengan et al., 2007). Savings, reducing, or efficient use of energy in agriculture are needed for sustainable production (Blanco-Canqui et al., 2006; Mendoza et al., 2003; Mendoza, 2005; 2007; Samson et al., 2001) for financial savings, fossil fuel resources preservation and air pollution reduction (Uhlin, 1998) and lesser greenhouse gas emission (Niggli et al., 2009; West and Marland, 2002). Application of integrated production methods are recently introduced to reduce production cost, efficiently use of human labour and other inputs, and to protect the environment.

Accounting the energy budget of agricultural production and post production is the first critical step in identifying the energy intensive processes or stages of production. In the past, researchers have studied the use of energy for wheat production in Iran (Shahan et al., 2008). In their study, they estimated that the total energy budget per hectare of wheat in Ardabil province was 10720.6 Mcal which is equivalent to 
940 liter diesel oil. Wheat as the main food of the Iranian requires large volume of oil from production-to-post production. In US, 272 liters of diesel oil is consumed from production-to-post production of 1 ton wheat (Pimentel et al., 2008).

Iran as an oil producing country can provide its own oil requirements at cheaper price. In 2007, Iran oil price was only half of the world price. The peak of world oil production (the time of maximum oil production) was in the year 2006 and now the world begin to experience shortage of oil supply which is expected to trigger an increase in oil price (Zittel et al., 2007). Iranians will no longer enjoy cheap oil price in the near future. By year 2030, Iran oil stock will be limited and becomes most limiting by year 2050 (Zittel et al., 2007).

The relationships between agricultural production and energy provides the clear signal to look at measures on how to efficiently use energy to help save oil and mitigate the possible oil shortage in the future. Knowing the processes or stages and the associated inputs for the particular stage or process are important in designing farm practices, or systems aimed at reducing the energy bill and in improving the energy use efficiency of that stage or the whole part of the production chain (Mendoza, 2007; Bony, 1993; Panesar and Fluck, 1993; Mudahar and Hignett, 1985). In this study, the energy consumed during the different stages of wheat production and post production in the province of Fars, Iran were estimated and the measures or practices which could reduce the energy costs are discussed.

\section{MATERIALS AND METHODS}

\section{The Study Area}

The study was done in Doroodzan dam farms, Fars province, Iran (Fig. 1). Fars province is located in the southern portion of Iran. Iran has three distinct climatic regions namely: 1, the mountainous area of the north and northwest with moderate cold winters and mild summers; 2 , the central regions, with relatively rainy mild winters, and hot dry 


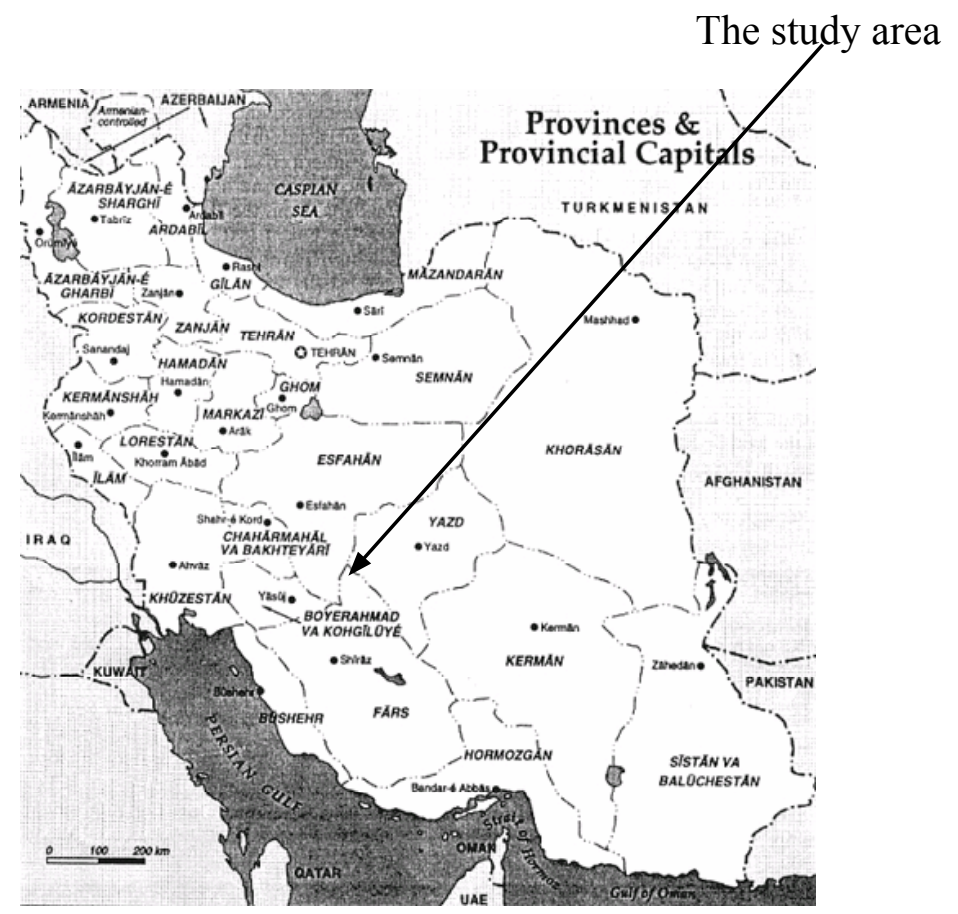

Figure 1. Map of Iran and the location of Fars province, the study area.

summers; and 3, the South and southeast, has moderate winters with very hot summers (http://en.wikipedia.org/wiki/Fars_Province). Doroodzan dam covers 110,000 ha of Fars irrigated land and it is located in first region of the northern part of Fars with average temperature of $16.8^{\circ} \mathrm{C}$ ( $4.7^{\circ}$ to $29.2^{\circ} \mathrm{C}$ range) and an average precipitation of $485 \mathrm{~mm}$ (http:// www.frrw.ir/english/TarhhaDetails.aspx?id=38).

Accounting of the Energy Bill of Wheat from Production to PostProduction

\section{Energy Inputs for Wheat Production}

Labour. The total labour incurred in growing 1 ha of wheat include land preparation (plowing and harrowing), seed preparation (seed mixing with fungicide and $\mathrm{P}$ fertilizer,and seed planting) and cultural 
management practices (irrigation, $\mathrm{N}$ fertilization, herbicide, pesticide, care and maintenance and harvesting).

Machinery. The total time of machine used for growing a hectare of wheat which include plowing, harrowing, seed planting and harvesting operations.

Diesel Fuel. The amount of diesel fuel used for machine operations in a hectare of wheat for plowing, harrowing, seed planting and harvesting.

Material Inputs. The inputs include 92 and $87.2 \mathrm{~kg} \mathrm{ha}^{-1} \mathrm{~N}$ and $\mathrm{P}$ fertilizer respectively, $5 \mathrm{~L} \mathrm{Fe}, 2 \mathrm{~kg}$ herbicide, $2 \mathrm{~kg}$ fungicide and $300 \mathrm{~kg}$ seeds.

Energy Usage for Irrigation. The energy uses for irrigating wheat include the energy inputs in dam and canal construction and the damn operation. For dam construction, the data were based in the construction of Hoover Dam (http://www.usbr.gov/lc/hooverdam/faqs/damfaqs.html) with the following specifications: Weight $=6,600,000$ tons, concrete volume $=3333459 \mathrm{~m} 3$, steel weight $=83764.9$ tons, construction period $=1806$ days, number of labour $=3,500 /$ day. The density of normal concrete is $2400 \mathrm{~kg} / \mathrm{m} 3$ (http://hypertextbook.com/facts/1999/ KatrinaJones.s.html).

- Weight of concrete: $3333459 \times 2.4=8,000,301$ tons

- Number of man days $=3,500 \times 1806=6321000 \mathrm{MD}$

Then, the ratio of concrete, steel and man day / weight of dam were estimated as follows; Concrete weight per weight of dam (ton): $8,000,301 / 6,600,000=1.212$; steel weight / weight of dam (ton): $83764.9 / 6,600,000=0.0127$; and the number of man day per weight of dam (tone): $6321000 / 6,600,000=0.957$.

Doroodzan dam in the Fars province, Iran, has the following features: Dam weight 11,300,000 tons and irrigation capacity of 110,000 hectares (http://www.frrw.ir/english/TarhhaDetails.aspx?id=38). Average dam lifespan is 150 years (http://www.dcr.virginia.gov/documents/dsvadams. pdf). Then, the above ratios were used in estimating the following data for Doroodzan dam: concrete weight, steel weight, number of man days, concrete weight ha-1 year ${ }^{-1}$, concrete energy ha ${ }^{-1}$ year $^{-1}$, steel weight ha- ${ }^{-1}$ year ${ }^{-1}$, steel energy ha- ${ }^{-1}$ year ${ }^{-1}$, number ha $^{-1}$ year $^{-1}$, number of man hours 
ha $^{-1}$ year $^{-1}$, man day energy ha- ${ }^{-1}$ year ${ }^{-1}$, total energy consume for irrigation, energy compare to LDOE, percent energy of inputs in production, cost of inputs with average cost of US\$ $0.5 \mathrm{LDOE} \mathrm{L}^{-1}$.

Canal construction energy consumed for excavation by machines is between $10-50 \mathrm{MJ} \mathrm{m}^{-3}$ and average of $20 \mathrm{MJm}^{-3}$ or $4.78 \mathrm{Mcal} \mathrm{m}^{-3}$ (http://www.princeton.edu/ globsec/publications/pdf/8_1 peterson. pdf). The length, depth and width of canal are 5,500,000 $\mathrm{m}, \overline{1} \mathrm{~m}$ and $2 \mathrm{~m}$, respectively. The volume of excavation per meter length of canal was $2.4 \mathrm{~m}^{3}$ and the concrete per meter length of canal was $675 \mathrm{Kg}$ (Pimentel et al., 1980). The average life span of canal is 25 years (http://www.dcr. virginia.gov/documents/dsvadams.pdf).

\section{Energy Inputs for Wheat Post Production}

Labour. The total time of labour utilized for post production of wheat produced from one hectare irrigated area which include the following: temporary silo (transportation and seed elevator), permanent silo (transportation in, seed elevator in and seed elevator out), milling (cleaning, conditioning, grinding, sieving and purifying), packing, loading the packed flour in elevator, unloading the packed flour from elevator, loading the packed flour in track, transporting to bakery, preparing the paste and baking bread).

Machinery .The total time of machine used for post production of wheat produced from one hectare irrigated area included the following: temporary silo (transportation and seed elevator), permanent silo (transportation in, seed elevator in and seed elevator out), milling (cleaning, conditioning, grinding, sieving and purifying), packing, flour elevator, transportation to bakery.

Silo. Data of a wheat silo included: Inside diameter (4.24 m), inside height $(22 \mathrm{~m})$, capacity $\left(278.3 \mathrm{~m}^{3}\right)$, empty weight of silo (12.95 ton), weightofsilage(178ton)(http://www.conairnet.com/product/documents/ Material\%20Storage\%20Spec\%20Sheets/Welded\%20Silos.pdf). The life span of silos was estimated at 50 years (http://th2.mofcom.gov.cn/ aarticle/supplydemandofchina/supply/200508/20050800335168.html).

Diesel Fuel and Electricity. The amount of diesel fuel and electricity for post production of wheat produced from one hectare 
irrigated area included: transportation (to temporary silo, to permanent silo and to bakery), seed elevator (temporary silo, permanent silo in, permanent silo out and flour), milling (cleaning, conditioning, grinding, sieving and purifying), packing and baking.

a. Elevator caoacity was $250 \mathrm{~kg} \mathrm{~h}^{-1}$ and power of $1 / 2 \mathrm{HP}$ or 0.32 Mcal (http://www.sehda.org/docs/wheat \%20milling.pdf).

b. Milling included cleaning, de-stoning and conditioning with capacity of $250 \mathrm{~kg} \mathrm{~h}^{-1}$ and power of $5.5 \mathrm{HP}$ or $3.5 \mathrm{mcal}$ (http://www. sehda.org/docs/wheat\%20milling.pdf) and grinding, sieving and purifying with power of $33 \mathrm{KWh} \mathrm{t}^{-1}$ or $28.37 \mathrm{Mcal}$ (http://www.ums. $\mathrm{dk} /$ Brochure\%20PDF/Short \%20Mill/ShortMill.pdf).

c. Baking- $18 \%$ of wheat is lost when it is processed into flour. (http://www.ums.dk/Brochure\%20PDF/Short\%20Mill/ShortMill.pdf).

1. The moisture content of bread is $28 \%$ (http://www.foodforlife. com/gluten-free-wheat-free-breads.html).

2. Baking cost by gas per $\mathrm{kg}$ of bread was US $\$ 0.059$ when the price of gas was US\$ 39.20 per $50 \mathrm{~kg}$ cylinder. Baking cost by electricity per $\mathrm{kg}$ of bread was US $\$ 0.047$ when price of electricity was U\$ 0.39 $\mathrm{kWh}^{-1}$. Baking cost by wood per $\mathrm{kg}$ of bread was U\$ 0.04 when the price of wood was U\$ 47 per $1000 \mathrm{~kg}$ (http://cigr-ejournal.tamu.edu/ submissions/ volume9/EE\%2007\%20002 \%20Jekayinfa\%20final\%201 2June2007.pdf).

The energy consumed for the production of $1 \mathrm{kwh}$ electricity is $2.004 \mathrm{Mcal}$ and the energy of $1 \mathrm{kwh}$ is $0.859 \mathrm{Mcal}$ and thus, the total energy for electricity is $2.863 \mathrm{Mcal}$ (Pimentel, 1980).

\section{Calculating the Total Energy Cost of Production to Post Production of Wheat}

The various stages of wheat production-to-post production and the inputs used for each stage were accounted for .The specific energy used for each operation and inputs were estimated as per energy coefficients used by various researchers (Table 1) and the energy consumed for the various operations were converted to litter diesel oil equivalent (LDOE) to have easier grasp of their energy usage. 
Table 1 . The energy coefficients used for wheat.

\begin{tabular}{llll}
\hline \multicolumn{1}{c}{ Input } & Unit & $\begin{array}{c}\text { Energy } \\
\text { (Mcal })\end{array}$ & \multicolumn{1}{c}{ Reference } \\
\hline Labour & Hour & 0.468 & Ozkan et al., 2004 \\
Machinery & Hour & 14.975 & Erdal et al., 2007 \\
Diesel fuel & Liter & 11.4 & $\begin{array}{l}\text { Pimentel } \text { et al., } 1980 \\
\text { http://www.shellgas.gr/site. }\end{array}$ \\
LPG & $\mathrm{Kg}$ & 10.96 & html?page=16\&lang=en \\
Wood & $\mathrm{Kg}$ & 4 & http://www.alibaba.com/ \\
Electricity & $\mathrm{KWh}$ & 2.863 & Pimpntel et al., 1980 \\
Fertilizer N (Urea) & $\mathrm{Kg}$ & 14.3 & Pimentel et al., 1980 \\
Fertilizer P & $\mathrm{Kg}$ & 2.97 & Esengun et al., 2007 \\
Fe & $\mathrm{Kg}$ & 2.36 & Esengun et al., 2007 \\
Seed & $\mathrm{Kg}$ & 3.51 & Ozkan et al., 2004 \\
Straw & $\mathrm{Kg}$ & 1.37 & Ozkan et al., 2004 \\
Bread & $\mathrm{Kg}$ & 2.7 & http://en.wikipedia.org/wiki/Bread \\
Chemicals & $\mathrm{Kg}$ & 28.66 & Canakci et al., 2005 \\
Concrete & $\mathrm{Kg}$ & 0.365 & Thampson et al., 1998 \\
Steel & $\mathrm{Kg}$ & 15.465 & Thampson et al., 1998 \\
\hline
\end{tabular}

The formula used in estimating the energy costs were as follows:

Equation 1. Inputs $\mathrm{ha}^{-1} \times$ Energy used $(\mathrm{Mcal})=$ energy consumed ha $^{-1}$

Equation 2. Energy consumed ha-1/11.4 Mcal/LDOE $=\mathrm{LDOE} \mathrm{ha}^{-1}$ ha $^{-1}$

Equation 3. LDOE ha-1 $\times 0.5 \$ \mathrm{~L}^{-1}$ of Oil $(\mathrm{LDOE})=$ cost of energy

Equation 4. Man day (md) ha-1 $\times$ US $\$ 10 \mathrm{md}=$ labour cost ha ${ }^{-1}$

Equation 5. Output Mcal ha $\mathrm{h}^{-1} /$ input $\mathrm{Mcal} \mathrm{ha}^{-1}=$ energy balance

\section{RESULTS AND DISCUSSION}

The total energy cost per of wheat from production to post production was estimated at $901 \mathrm{LDOE} \mathrm{ha}^{-1}$ or $10271 \mathrm{Mcal} \mathrm{ha}^{-1}$ (Table 2 ). The energy cost in the field production of wheat was estimated at 422.7 $\mathrm{LDOE} \mathrm{ha}^{-1}$ or $4819 \mathrm{Mcal} \mathrm{ha}^{-1}$ (47\% of the total energy used, Fig.2) 


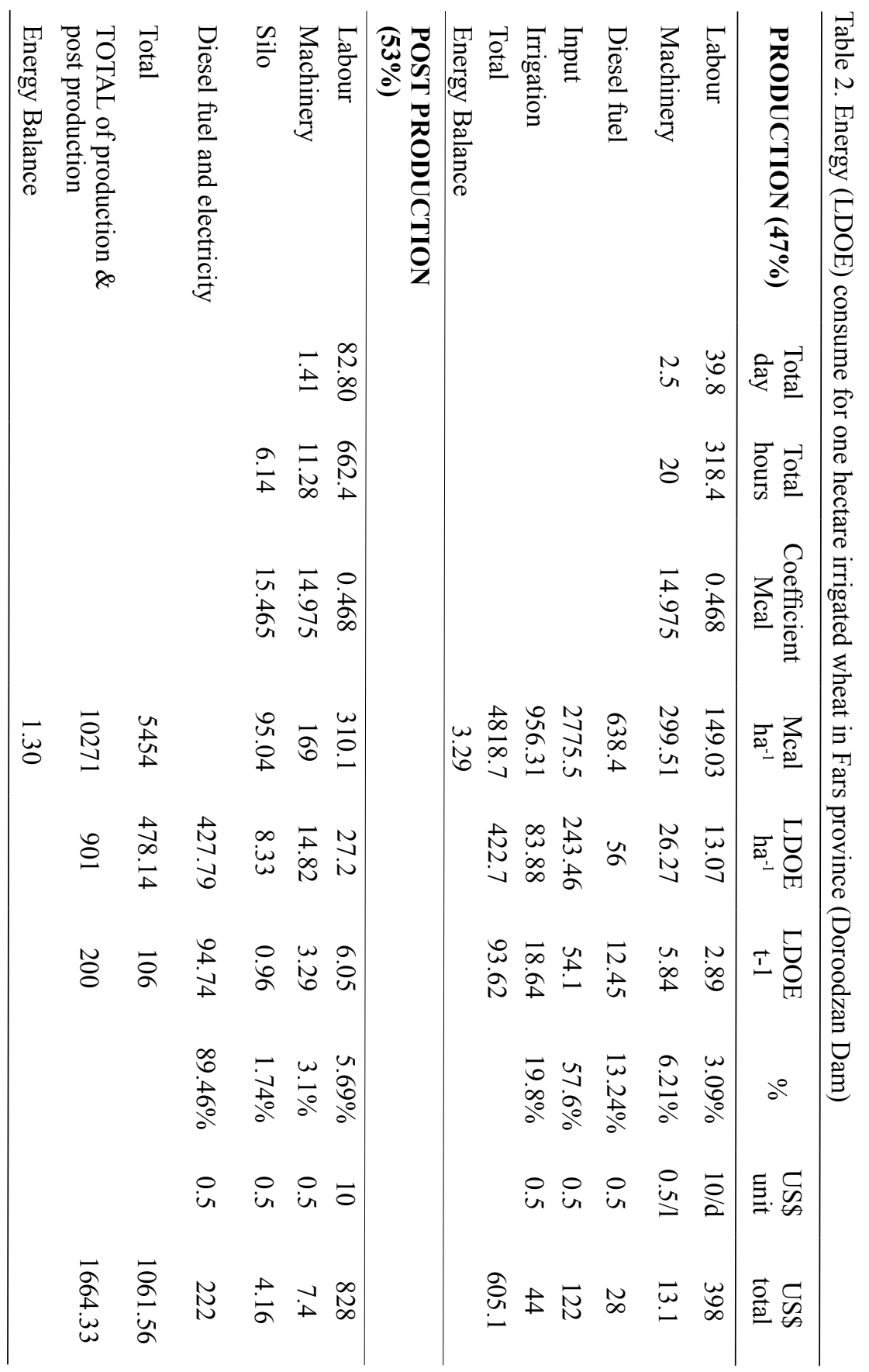




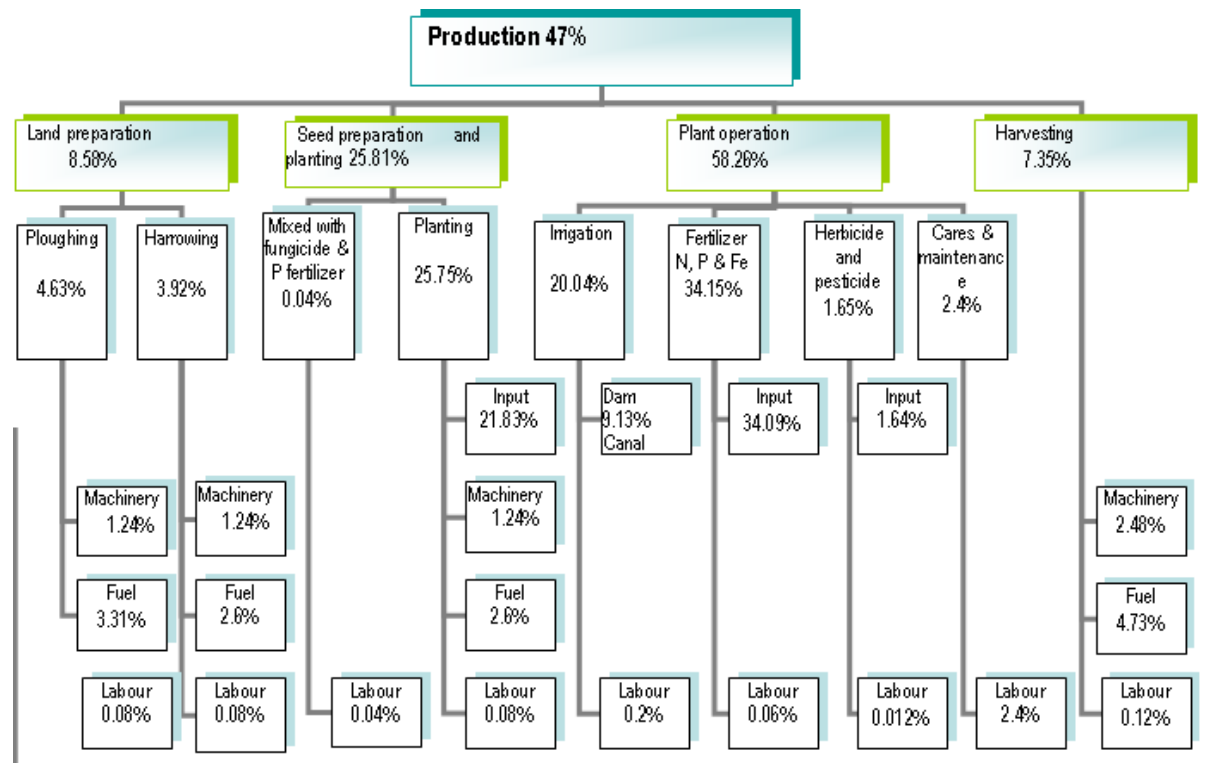

Figure 2. Energy consumed (\%) for producing 1 hectare irrigated wheat in Fars province, Iran.

and 478.14 LDOE ha-1 or $5454 \mathrm{Mcal} \mathrm{ha}^{-1}$, for post production $(54 \%$ of the total energy used). It is quite close to the estimated energy used in wheat production in US at $45 \%$ and post production at 55\% (Pimentel, 2008). The total energy cost of 1 ton wheat from production-to-post production was estimated at $200 \mathrm{LDOE}$ while the total energy cost for 1 ton bread was estimated at 181.4 LDOE. In U.S, it is $272 \mathrm{LDOE} /$ ton as reported by Pimentel (2008). The energy cost of 1 ton wheat in the production level was equivalent to $93.62 \mathrm{LDOE}$ (input $54 \mathrm{LDOE}$, irrigation 18.64 LDOE, fuel 12.45 LDOE, machinery 5.84 LDOE and labour 2.89 LDOE) and in the post production level at $106 \mathrm{LDOE}$ (fuel 94.78 LDOE, labour 6.05 LDOE, machinery 3.29 LDOE and silo 0.96 LDOE).

At production level for one hectare wheat(Fig 2), planting operations consumed the highestenergy estimated at $58.26 \%$ of production. Fertilizer $\mathrm{N}, \mathrm{P}$ and $\mathrm{Fe} 34.15 \%$ consumed the highest followed by irrigation at $20.04 \%$ (dam-9.13\%, canal-10.71\%, and labour-0.2\%), maintenance $2.4 \%$, herbicide and pesticide at $1.65 \%$ (inputs $1.64 \%$ and labour $0.01 \%$ ). The next group of energy consumer was seed preparation and 
planting at $25.81 \%$ of production which included planting $25.75 \%$ (seed $21.83 \%$, fuel $2.6 \%$, machinery $1.24 \%$ and labour $0.08 \%$ ) and mixing seed, fungicide and $\mathrm{P}$ fertilizer $0.04 \%$. Land preparation consumed

\section{Post production 53\%}

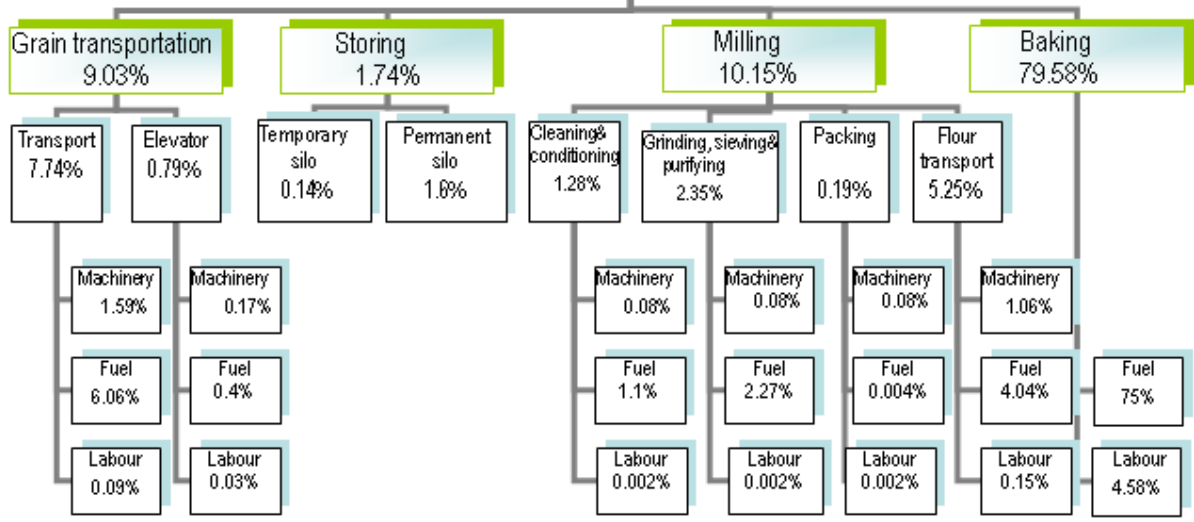

Figure 3. Energy consumed (\%) for post production 1 hectare irrigated wheat in Fars province, Iran.

$8.58 \%$ of the total energy bill in production which included ploughing at $4.63 \%$ (fuel $3.31 \%$, machinery $1.24 \%$, labour $0.08 \%$ ) and harrowing at $3.92 \%$ (fuel $2.6 \%, 1.24 \%$ and $0.08 \%$ ). The lowest energy consumed was in harvesting at $7.35 \%$ of the total energy bill of production (fuel $4.73 \%$, machinery $2.48 \%$ and labours $0.12 \%$ ).

For the post production stage (Fig. 3), baking was the highest energy consumer at $79.58 \%$ (fuel $75 \%$ and labour $4.58 \%$ ) followed by milling at $10.15 \%$ of the total post production energy bill. This included flour transportation at $5.25 \%$ (fuel $4.05 \%$, machinery $1.06 \%$ and labour $0.15 \%$ ), grinding, sieving and purifying at $2.35 \%$ (fuel $2.27 \%$, machinery $0.08 \%$ and labour $0.002 \%$ ), cleaning and conditioning $1.28 \%$ (fuel $1.1 \%$, machinery $0.08 \%$ and labour $0.002 \%$ ) and packing $0.19 \%$ (machinery $0.08 \%$, fuel $0.004 \%$ and labour $0.002 \%$ ). Grain transportation consumed $9.03 \%$ of post production energy bill which included transportation $7.74 \%$ (fuel $6.06 \%$, machinery $1.59 \%$ and labour $0.09 \%$ ) and grain elevator $0.79 \%$ (fuel $0.4 \%$, machinery $0.17 \%$ and labour $0.03 \%$ ). The lowest energy consumer was storing bread at $1.74 \%$ of post production 
energy cost (permanent silo $1.6 \%$ and temporary silo $0.14 \%$ ).

The total expenses for wheat production were estimated at US\$1664.33 ha-1 (Table 2). The most expensive input in irrigated wheat from production-to-post production was labour which consumed $66 \%$ of production and $78 \%$ of post production expenses. The difference in energy cost between production and post production was only $8 \%$ but the expenses increased in post production by 1.76 than production because the latter required more labour cost.

\section{Energy Balance}

Table 3. Energy balance for 1 hectare irrigated wheat in Fars province (Doroodzan Dam)

\begin{tabular}{lccccc}
\hline PRODUCTION & Kg ha $^{-1}$ & $\begin{array}{c}\text { Efficiency } \\
\text { of output } \\
\text { Mcal }\end{array}$ & $\begin{array}{c}\text { Output } \\
\text { Mcal ha }^{-1}\end{array}$ & $\begin{array}{c}\text { Input } \\
\text { Mcal ha }^{-1}\end{array}$ & $\begin{array}{c}\text { Energy } \\
\text { balance }\end{array}$ \\
\hline Raw wheat & 4515 & 3.51 & 15847.65 & 4819 & 3.29 \\
Straw & 2113 & 1.37 & 2895 & 4819 & 0.6
\end{tabular}

POST PRODUCTION

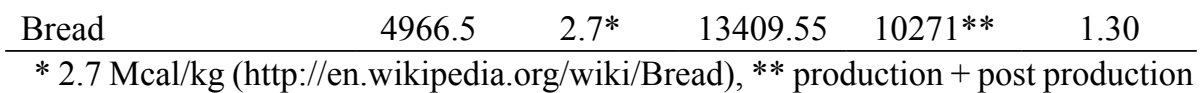
$=10,271 \mathrm{Mcal}$

The energy output for production of grain and straw was estimated at $15847.65 \mathrm{Mcal} \mathrm{ha}^{-1}$ and $2895 \mathrm{Mcal} \mathrm{ha}^{-1}$, respectively (Table 3). The energy input of production was $4819 \mathrm{Mcal} \mathrm{ha}^{-1}$ and the energy balance of production for grain and straw was estimated at 3.29 and 0.6 , respectively. For post production, the bread produced per hectare production level was estimated at $4966.5 \mathrm{~kg} \mathrm{ha}^{-1}$, the energy requirements at 13409.55 Mcal ha ${ }^{-1}$ and the input energy at 10,271 Mca ha ${ }^{-1} 1$. The energy balance for bread (post production) was estimated at 1.30.

The energy cost of wheat production in Fars province, Iran (4819 Mcal ha-1) was slightly higher than in the US (4239 Mcal ha-1) (Pimentel et al., 2008). The total energy consumed by fuel, labour, irrigation and machinery have no significant differences with that of the US, but the volume of seeds required for planting is 5 times higher in Iran. The average yields in Fars province is $4.5 \mathrm{t} \mathrm{ha}^{-1}$ while only $2.9 \mathrm{t} \mathrm{ha}^{-1}$ in US.. The energy cost ratio (production:post production ratio) for $1 \mathrm{~kg}$ wheat 
in Fars province, Iran is about 47:53 while it is 45:55 in US (Pimentel et al., 2008). Iranians are buying their breads directly from bakeries and they use their own fabric bags for packaging and thus no energy costs for packaging were included in the estimations. The energy cost for milling in Iran was 50\% lower than in the US but the energy cost of baking in the former was $100 \%$ higher than the latter.

To reduce the energy incurred in production and post-production of wheat, it is necessary to look into all the energy requiring processes as follows:

1) The energy cost of production is related to inputs at $57.60 \%$ where $27.53 \%$ of the energy cost of production was $\mathrm{N}$ fertilizer. Nitrogen and other fertilizers and chemicals could be reduced by crop residues recycling (Badgley et al., 2007, Mendoza , 2003; Samson et $a l ., 2001)$ or by returning wheat straw to the field and spraying them with microorganisms to facilitate decomposition (Parr et al.,1994; Higa, 1991); planting of alfalfa in rotation to wheat (alfalfa with association of Rhizobial bacteria is able to absorb the $\mathrm{N}$ from the air and store in the root nodules) can decrease $\mathrm{N}$ requirements, planting of resistant varieties to pest and diseases to minimize pesticide use .

2) Water is the most limiting factor for agriculture and $20 \%$ of the energy cost of production is related to irrigation. Savings in water lost through seepage in the irrigation canal can be achieved by covering the canal by concrete . This could save water up to $80 \%$ and decrease the energy cost of irrigation as pointed out by many researchers (Singh et al., 2007; and Shahan et al. 2008). It is correct that the initial costs would be high but the return in terms of lower energy cost of irrigation could more than offset the initial costs. Besides, water will soon be the limiting factor not only in wheat but other crops which should be grown also for balanced nutrition.

3) The embedded energy from machinery and fuel used to operate them consumed $6.21 \%$ and $13.24 \%$ of production cost, respectively. The average life span of machine in Iran is only 6 years but in countries where preventive maintenance and care of the machines are being done, the life span of machine reached up to 15 years or more. Using machine longer reduces the energy cost for their manufacture. Proper machine preventive maintenance will reduce the energy cost of machine and 
fuel.

4) Labor is only $3.09 \%$ of the energy cost in wheat production but it is the most costly, monetary wise, as $66 \%$ of wheat production expenses are related to labour. Most of the labour cost $(75.37 \%)$ is incurred for guarding their crops against animal intrusions. Unity of farmers in tending their animals shall decrease the labour cost.

5) The post-production energy bill was estimated at 53\% of the total. But $79.58 \%$ of this was consumed in baking bread. The energy consumed for baking $1 \mathrm{~kg}$ bread with electricity was at $0.344 \mathrm{Mcal}$ while it was $0.824 \mathrm{Mcal}$ with LPG. Using of electricity instead of LPG can decrease the energy cost of baking by 2.4 times.

6) Construction of post production facility near the farm can generate substantial fuel savings because wheat has some secondary products ( $7 \%$ bran, $1 \%$ ash and $10 \%$ impurities) which can be used in the farm. After flour production, bran can be fed to livestock and other residues (ash and impurities) can be left in the farm and thus reducing the cost of energy in transporting them back in the farm. Every year, $18 \%$ of the gross yields are unnecessarily delivered to the cities. Iran produced 14.3 million tons of wheat in 2005. From these amounts, 2.5 million tons comprise the secondary products. At $4 \mathrm{~L}$ diesel oil required for delivery of 1 ton of wheat, the total oil used for transporting of 2.5 million tons secondary product was estimated at 10 million L diesel oil. Transportation to and from the city would consume about 20 million L of diesel oil to free the cities with these secondary products. This could have been avoided and savings are generated if factories are situated near the farms. It is important that the government should issue policy directives that future factories will be built near the farms.

\section{CONCLUSION}

The total energy input for irrigated wheat from production to post production in Fars province, Iran, was estimated at $901 \mathrm{LDOE} \mathrm{ha}^{-1}$ or $10271 \mathrm{Mcal} \mathrm{ha}^{-1}$. The energy cost in the production of wheat was equivalent to $422.7 \mathrm{LDOE}$ or $4819 \mathrm{Mcal}$ ( $47 \%$ of the total energy used) and $478.14 \mathrm{LDOE}$ or $5454 \mathrm{Mcal}$ (53\% of the total energy used) for 
post production. From production-to-post production, the energy bill was estimated 200 LDOE per ton of irrigated wheat and total energy cost for 1 ton bread was estimated at 181.4 LDOE. One tone of wheat produced consumed 93.62 LDOE and while post production consumed 106 LDOE.

The energy balance for production and post production was estimated at 3.29 and 1.30, respectively. The associated energy bill in the manufacture of production inputs led to their highest energy cost at $57.6 \%$ of production cost (nitrogen fertilizer $27.53 \%$, seeds $21.83 \%$, fertilizer P and $\mathrm{Fe} 5.62 \%$ and other chemicals $2.83 \%$ ).

Fuel, the highest energy cost of post production contributed $89.46 \%$ of post production cost which included baking (76\%), transportation $(10.1 \%)$ and others $(3.77 \%)$.

The most expensive input in irrigated wheat from production to post production was labour with $66 \%$ of wheat production and $78 \%$ of post production expenses. The difference between energy cost of production and post production was only $8 \%$ but the expenses in the latter were 1.76 times higher than the former because post production had higher labour cost.

\section{REFERENCES}

ALAM, M. S., M. R. ALAM, and K. K. ISLAM. 2005. Energy flow in agriculture: Bangladesh. American Journal of Environmental Science 1(3):213-220.

BADGLEY et al. 2007. Organic agriculture and the global food supply. Renewable Agriculture and Food Systems 22(2):86-108.

BLANCHO-CANQUI, H. et al. 2006. Rapid Changes in Soil Carbon and structural properties due to stove removal from no-till corn plots. Soil Science 171(6):468-482. 
BONY, S. 1993. Is agriculture using more and more energy? A French case study. Agricultural Systems 43:51-56.

CONKI, M., M. TOPACKI, I. AKINCI, and A. OZMARZI. 2005. Energy use pattern of some field crops and vegetable production: case study Antalya region, Turkey. Energy Conservation \& Management 46:655-66.

ERDAL G., K. ESENGUN, H. ERDAL, and O. GUDOZ. 2007. Energy use and economical analysis of sugar beet production in Tokat province of Turkey. Energy 32:35-41.

ESENGUN K., H. ERDAL and K. O. GUDOZ. 2007. Input-output energy analysis in dry apricot production of turkey. Energy Conservation \& Management 48:592-598.

HIGA, T. 1991. Effective microorganisms: A biotechnology for mankind. p.8-14. In Proceedings of the First International Conference on Kyusei Nature Farming (J. F. Parr, S. B. Hornick, and C. E. Whitman, eds). U.S. Department of Agriculture, Washington, D.C., USA.

HUNG P., T. MAEDA, D. MISKEILY, R. TSUMORI, and A. MORITA. 2008. Physicochemical characteristics and fine structure of high-amylose wheat starches isolated from Australian wheat cultivars. Carbohydrate polymers 71(4):656-663.

MCLAUGHLINM, N. B. et al. 2000. Comparison of energy inputs for inorganic fertilizer and manure based corn production .Canadian Agricultural Engineering 42(1):13-35.

MENDOZA, T. C., R. SAMSON, and T. HELWIG.2003. Evaluating the many benefits of sugarcane trash farming systems. Philippine Journal of Crop Science 27(1): pp. 43-51.

MENDOZA, T. C. 2007. Energetics of Ethanol Production from 
Sugarcane and its Implications. Asian Life Science Journal 16(2):115-136.

MENDOZA, T. C. 2005. An Energy-Based Analysis of Organic, Low External Input Sustainable and Conventional Agriculture. Phil. Agric. Scientists 88(3):257-267.

MUDAHAR, M. S. and T. P. HIGNET. 1985. Energy efficiency in nitrogen fertilizer production. Energy in Agriculture 4:159-77.

NIGGLI, U., A. FLIEBBACH, P. HEPPERLY, and N. SCIAALABBA. 2009. Low Greenhouse Gas Agriculture: Mitigation and Adaptation Potential of Sustainable Farming Systems. FAO. April 2009. Rev. 2-2009. ftp://ftp.fao.org/docrep/fao/010/ ai781e/ai781e00.pdf Accesed June 2010.

OZKAN, B., H. AKCAOZ, and C. FERT. 2004. Energy input-output analysis in Turkish agriculture. Renewable energy 29:39-51.

PARR, J. F., S. B. HORNICK, and D. D. KAUFMAN. 1994. Use of microbial Inoculants and organic fertilizers in agricultural production. In :Proceedings of the International Seminar on the Use of Microbial and Organic Fertilizers in Agricultural Production. Food and Fertilizer Technology Center, Taipei, Taiwan.

PANESARBS and R. C. FLUCK. 1993. Energy productivity of a production system: Analysis and measurement. Agricultural Systems 43:415-437.

PATRIQUIN, D. G. 1992. Nitrogen fixation in sugarcane litter. Biological Agriculture \& Horticulture 1:39-64.

PIMENTEL, D. 1980. Handbook of Energy Utilization in Agriculture. CRC Press Inc. 15-24. 
PIMENTEL, D., and M. PIMENTEL. 2008. Food, energy and society. CRC Press Inc. p. 108-249.

SAMSON, R., T. HELWIG, D. STOHL, A. DE MAIO, P. DUXBURY, T. MENDOZA, and A. ELEPANO. 2001. Strategies for enhancing biomass utilization in the Philippines. USDOE National Renewable Energy Laboratory, Colorado, USA. NREL/SR-510-30813.

SHAHAN, S., A. JAFARI, H. MOBLI, S. REFIEE, and M.KARIMI. 2008. Energy use and economical analysis of wheat production in Iran: A case study from Ardabil province. Journal of Agriculture Technology 4(1): 77-88.

SINGH, H., A. K. SINGH, H. L. KUSHWAHA, and A. SINGH. 2007. Energy consumption pattern of wheat production in India. Energy 32:1848-1854.

THAMPSON, W. 1998. Sustainable landscape construction. Island Press Washington, D.C. $268+$ xxi.

UHLIN, H. 1998. Why energy productivity is increasing: an I-O analysis of Swedish agriculture. Agric Systems 56(4):65-443.

WEST, T. O, and G. MARLAND. 2002. A synthesis of carbon sequestration, carbon emissions, and net carbon flux in agriculture: Comparing tillage practices in the United States. Agriculture, Ecosystems and Environment 91:217-232.

ZITTEL, W., L. BOLKOW, and J. SCHINDLER. 2007. Crude Oil: The Supply Outlook. www.energywatchgroup.org. Accessed July 2008. 